九州大学学術情報リポジトリ

Kyushu University Institutional Repository

\title{
A Numerical Taxonomic Study of the Genus Andrena (Hymenoptera, Andrenidae) of Japan
}

Tadauchi, 0samu

Entomological Laboratory, Faculty of Agriculture, Kyushu University

https://doi.org/10.5109/23748

出版情報：九州大学大学院農学研究院紀要. 26 (4)，pp. 169-191，1982-07. Kyushu University バージョン：

権利関係: 


\title{
A Numerical Taxonomic Study of the Genus Andrena (Hymenoptera, Andrenidae) of Japan*
}

\author{
Osamu Tadauchi \\ Entomological Laboratory, Faculty of Agriculture, \\ Kyushu University 46-01, Fukuoka 812
}

(Received January 26, 1982)

\begin{abstract}
Numerical taxonomic relationships of eighty-five OTU's (operational taxonomic units) or taxa of the genus Andrena (Hymenoptera, Andrenidae) of Japan were studied based on 130 adult female morphological characters using five clustering methods. The phenogram derived from distance coefficient was much more congruent with the original matrix and the conventional classification than that derived from correlation coefficient. The position of each OTU was examined at the subgeneric level. The results were in considerable agreement with current classification. Twenty-three groups were developed in the 85 OTU's of the genus Andrena of Japan. Differences between numerical taxonomy and conventional classification were as follows: 1) the ishikawai-taniguchiae species group of the subgenus Holandrena was recognized better to be raised to the subgeneric level;2) amamiensis was away from the subgenus Notandrena; 3) the knuthi-knuthi okinawana group was transferred to the subgenus Chlorandrena.
\end{abstract}

\section{INTRODUCTION}

In Japan the Andrenidae are represented by only two genera, Andrena and Panurginus, which belong to the independent subfamily, Andreninae and Panurginae, respectively (Hirashima, 1962). The genus Andrena which is one of the principal genera in the Japanese Apoidea is abundant both in species and individuals. Sixty-one species, one of which was divided into two subspecies, of the genus Andrena in Japan were classified into 20 subgenera by Hirashima (1962-1966). Tadauchi (1975) already studied numerical phenetic relationships of the genus Andrena of Japan based on 70 female characters derived from 60 species using three clustering methods and principal component analysis. Since the correspondence between conventional classification and numerical taxonomic grouping was found, Hirashima and Tadauchi (1975) erected a new subgenus Oreomelissa.

Recently Tadauchi (in preparation), Hirashima and Tadauchi (in prepara. tion), and Hirashima, Tadauchi and Matsumura (in preparation) made a revisional study of the genus Andrena of Japan and found 13 new species. In the present study 85 OTU's (operational taxonomic units) or taxa including

* Contribution from the Entomological Laboratory, Faculty of Agriculture, Kyushu University, Fukuoka (Ser. 3, No. 110). 
color forms and geographical forms as well as the above new species were investigated based on 130 female morphological characters. The purpose of the present study is to examine the position of each OTU at the subgeneric level. Further intent of this study is to make comparisons between the phenograms derived from correlation and distance matrices and comparisons among the phenograms based on the five clustering methods.

\section{MATERIAL AND METHODS}

\section{Material}

The material used in the present study was based on female specimens of 85 OTU's of the genus Andrena of Japan. The material is listed in Table 1 with subgeneric codes and OTU's code numbers. Among 85 OTU's there are 76 species, two subspecies of $A$. knuthi, two subspecies of $A$. (Hoplandrena) sp. 1 (Hirashima and Tadauchi, in preparation), two color forms of $A$. mikado (A is a blackish form and $\mathrm{B}$ is a fulvous one), four geographical forms of $A$. takachihoi (A is from Kyushu Mainland, B is from the Tsushima Island, both $\mathrm{C}$ and $\mathrm{D}$ are from Central Honshu), two geographical forms of $A$. edashigei (A is from the Amami Island and $B$ is from the Okinawa-Honto Island), two geographical forms of $A$. komachi (A is from Kyushu and $\mathrm{B}$ is from Hokkaido), and two geographical forms of A. kaguya (A is from Kyushu and B is from Hokkaido). Since this study was restricted to the adult females, A. macroceps

Table 1. Eighty-five OTU's (taxa) of the genus Andrena of Japan used in the present study.

\begin{tabular}{|c|c|c|c|}
\hline Subg. code & Subgenus & IU code & OTU \\
\hline AND & Andrena & 1 & brevihirtiscopa Hirashima 1962 \\
\hline$"$ & $A$. & 2 & mikado Strand et Yasumatsu 1938 , form A \\
\hline$"$ & $A$. & 3 & bombiformis Yasumatsu et Hirashima 1962 \\
\hline$"$ & $A$. & 4 & ishiharai Hiras hima 1953 \\
\hline$"$ & $A$. & 5 & nawai Cockerell 1913 \\
\hline$" 1$ & $A$. & 6 & esakii Hirashima 1957 \\
\hline$"$ & $A$. & 7 & longitibialis Hirashima 1962 \\
\hline$" \prime$ & $A$. & 8 & maukensis Matsumura 1911 \\
\hline$" 1$ & $A$ & 9 & shirozui Hirashima 1962 \\
\hline$"$ & $A$. & 10 & hondoica Hirashima 1962 \\
\hline$"$ & $A$. & 11 & aburana Hirashima 1962 \\
\hline " & A. & 12 & saragamineensis Hirashima 1962 \\
\hline$\mu$ & A. & 13 & benefica Hirashima 1962 \\
\hline $\mathrm{CAL}$ & Calomelissa & 14 & prostomias Pérez 1905 \\
\hline " & Cal. & 15 & tsukubana Hirashima 1957 \\
\hline ORE & Oreomelissa & 16 & mitakensis Hirashima 1963 \\
\hline " & $O$. & 17 & kamikochiana Hirashima 1963 \\
\hline CHL & Chlorandrena & 18 & taraxaci chikuzenensis Hiras hima 1957 \\
\hline$" 1$ & ? Chl. & 19 & knuthi Alfken 1900 \\
\hline$"$ & ? Chl. & 20 & knuthi okinawana Matsumura et Uchida 1926 \\
\hline $\mathrm{CNE}$ & Cnemidandrena & 21 & seneciorum Hirashima 1964 \\
\hline$" 1$ & Cnem. & 22 & maetai Hirashima 1964 \\
\hline$"$ & Cnem. & 23 & alhicaudata Hirashima 1966 \\
\hline $\mathrm{EU}$ & Euandrena & 24 & hebes Pérez 1905 \\
\hline$" 1$ & $E$. & 25 & stellaria Hirashima 1964 \\
\hline$" \prime$ & $E$ & 26 & ruficrus rabicrus Hirashima 1957 \\
\hline " & E. & 27 & takachihoi Hirashima 1964 , form A \\
\hline
\end{tabular}


Table 1. Continued.

\begin{tabular}{|c|c|c|c|}
\hline Subg. code & Subgenus & OTU code & OTU \\
\hline GYM & Gymnandrena & 28 & watasei Cockerell 1913 \\
\hline$" \prime$ & $G$ & 29 & wulungshanensis Yasumatsu 1935 \\
\hline$" \prime$ & $G$. & 30 & parathoracica Hirashima 1957 \\
\hline$" \prime$ & $G$. & 31 & okabei sapporensis Hirashima 1957 \\
\hline$"$ & $G$. & 32 & edashigei Hirashima 1960 , form A \\
\hline$\prime \prime$ & $G$ & 33 & sasakii Cockerell 1913 \\
\hline HAB & Habromelissa & 34 & omogensis Hirashima 1957 \\
\hline HOL & Holandrena & 35 & valeriana Hirashima 1957 \\
\hline$\prime \prime$ & Hol. & 36 & ishikawai Hirashima 1958 \\
\hline$"$ & Hol. & 37 & taniguchiae Hirashima 1958 \\
\hline HOP & Hoplandrena & 38 & dentata Smith 1879 \\
\hline$" 1$ & Hopl. & 39 & miyamotoi Hirashima 1964 \\
\hline " & Hopl. & 40 & sachalinensis Yasumatsu 1930 \\
\hline$\prime \prime$ & Hopl. & 41 & pruniphora Hirashima 1964 \\
\hline MIC & Micrandrena & 42 & hikosana Hirashima 1957 \\
\hline$"$ & Micr. & 43 & brassicae Hirashima 1957 \\
\hline " & Micr. & 44 & kaguya Hirashima 1965 , form A \\
\hline$"$ & Micr. & 45 & komachi Hirashima 1965 , form A \\
\hline$"$ & Micr. & 46 & sublevigata Hirashima 1966 \\
\hline$"$ & Micr. & 47 & falsificissima Hirashima 1966 \\
\hline MIT & Mitsukuriella & 48 & japonica (Smith) 1873 \\
\hline & Mits. & 49 & fukaii Cockerell 1914 \\
\hline NOT & Notandrena & 50 & nitidiuscula Schenck 1853 \\
\hline$" \prime$ & $? N$ & 51 & richardsi Hirashima 1957 \\
\hline$\prime \prime$ & $? N$ & 52 & amamiensis Hirashima 1960 \\
\hline PAR & Parandrena & 53 & yasumatsui Hirashima 1952 \\
\hline PLA & Plastandrena & 54 & astragalina Hirashima 1957 \\
\hline POE & Poecilandrena & 55 & fukuokensis Hirashima 1952 \\
\hline SIM & Simandrena & 56 & opacifovea Hirashima 1952 \\
\hline$" \prime$ & Sim. & 57 & kerriae Hirashima 1965 \\
\hline STE & Stenomelissa & 58 & halictoides Smith 1869 \\
\hline TAE & Taeniandrena & 59 & ezoensis Hirashima 1965 \\
\hline TRA & Trachandrena & 60 & foveopunctata Alfken 1932 \\
\hline & Tra. & 61 & haemorrhoa japonibia Hirashima 1957 \\
\hline ORE & Oreomelissa & 62 & coitana pilosodorsata Alfken 1929 \\
\hline LAR & Larandrena & 63 & echizenia Hirashima et Haneda 1973 \\
\hline & $L$. & 64 & fukuiana Hirashima et Haneda 1973 \\
\hline AND & Andrena & 65 & mikado Strand et Yasumatsu 1938, form B \\
\hline & A. & 66 & sp. $1^{*}$ \\
\hline "I & A. & 67 & sp. $2^{*}$ \\
\hline$"$ & A. & 68 & sp. $3^{*}$ \\
\hline$" 1$ & $A$. & 69 & sp. $4 * *$ \\
\hline EU & Euandrena & 70 & sp. $1^{* *}$ \\
\hline$"$ & $E$. & 71 & takachihoi, form B \\
\hline$"$ & $E$. & 72 & takachihoi, form $\mathrm{C}$ \\
\hline$"$ & $E$ & 73 & takachihoi, form D \\
\hline GYM & Gymnandrena & 74 & edashigei, form $\mathrm{B}$ \\
\hline HOP & Hoplandrena & 75 & sp. 1 ssp. $1 * *$ \\
\hline "1 & Hopl. & 76 & sp. 1 ssp. $2 * *$ \\
\hline MIC & Micrandrena & 77 & sp. $1 * * *$ \\
\hline " & Micr. & 78 & sp. $2 * * *$ \\
\hline$"$ & Micr. & 79 & sp. $3 * * *$ \\
\hline$" \prime$ & Micr. & 80 & sp. $4 * * *$ \\
\hline$" \prime$ & Micr. & 81 & komachi, form B \\
\hline$"$ & Micr. & 82 & kaguya, form B \\
\hline SIM & Simandrena & 83 & sp. $1 * *$ \\
\hline "I & Sim. & 84 & sp. $2 * *$ \\
\hline "1 & Sim. & 85 & sp. $3 * *$ \\
\hline
\end{tabular}

* Hirashima, Tadauchi and Matsumura, in preparation

** Hirashima and Tadauchi, in preparation

*** Tadauchi, in preparation 
(Matsumura) 1912, which was classified into the subgenus Hoplandrena by Hirashima (1964), was excluded because of the discovery of only a single male specimen. A. praecociformis Cockerell 1911, which seemed to belong to the subgenus Euandrena, was also excluded because of the discovery of only a few male specimens.

\section{Characters}

A total of 130 morphological characters were used in this study. A char. acter was defined according to the concept of the phenetic school, i.e., as a feature that varies among the OTU's used and can not be further subdivid. ed logically. The characters and the numbers of the states for the characters are listed in Table 2. The qualitative and quantitative characters were distributed over various regions of the body as follows: body size character 1 ; structural character 81 (head 33 , thorax 23 , wings 6 , legs 6 , metasoma 13); pubescence character 40 ; and body color character 8 . The number of alternative states shown clearly in OTU's determined the number of state codes for that character. Quantitative or multistate characters were coded taking the sizes and ranges of the characters over all the OTU's into consideration. The code numbers of multistate characters ranged from 1 to 5 . The average state was used from the characters varying among individual representatives of the OTU's. After the characters were coded for each OTU, these data were keypunched and processed on FACOM M-200 computer at the Computer Center of Kyushu University.

Table 2. One hundred and thirty characters used in the present study with the numbers of the states for the characters.

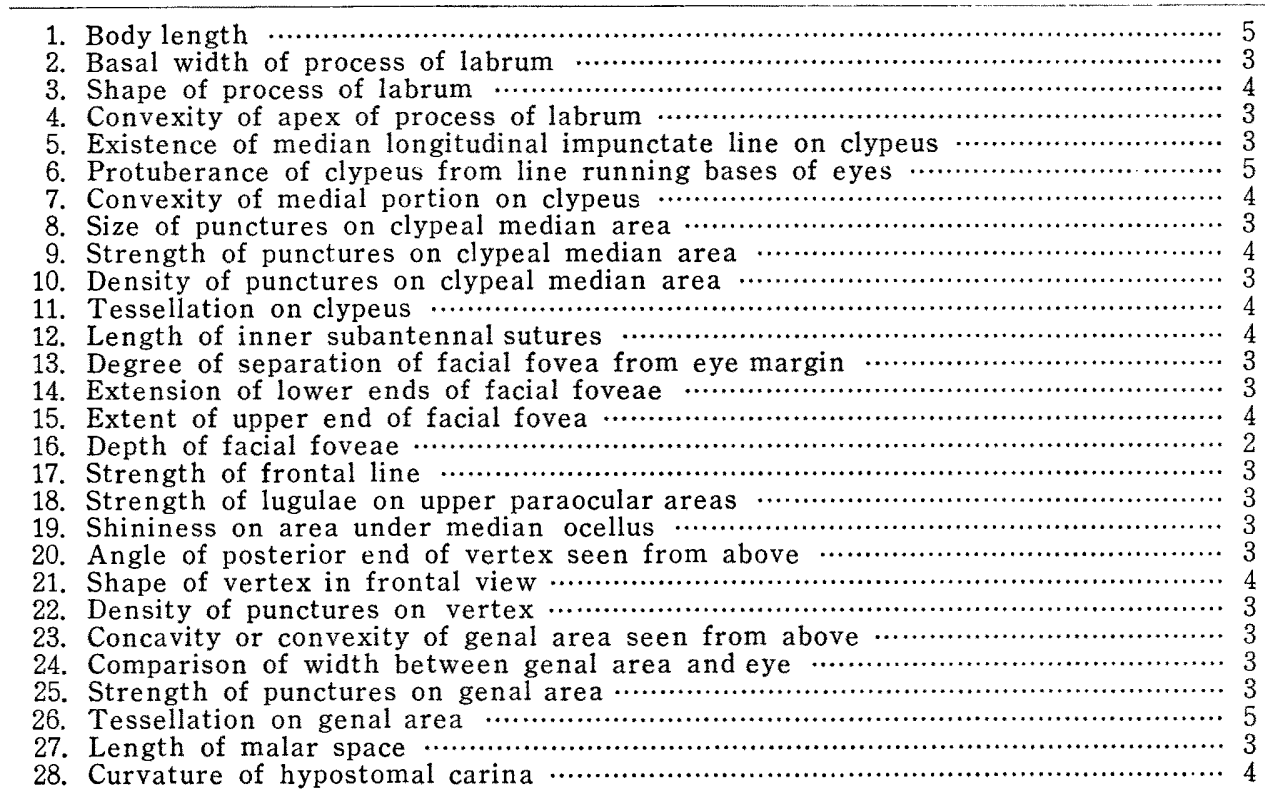


Table 2. Continued.

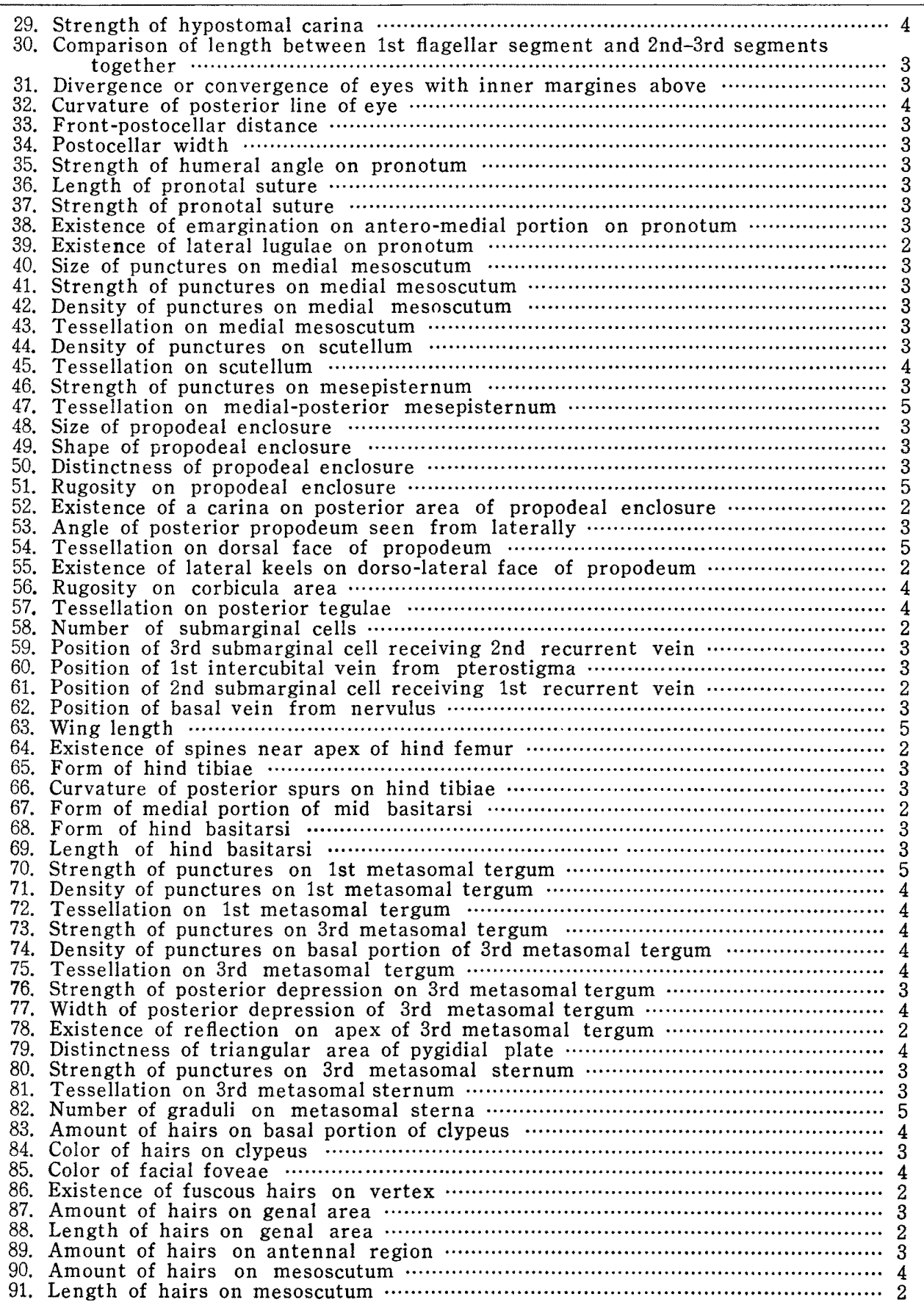


Table 2. Continued.

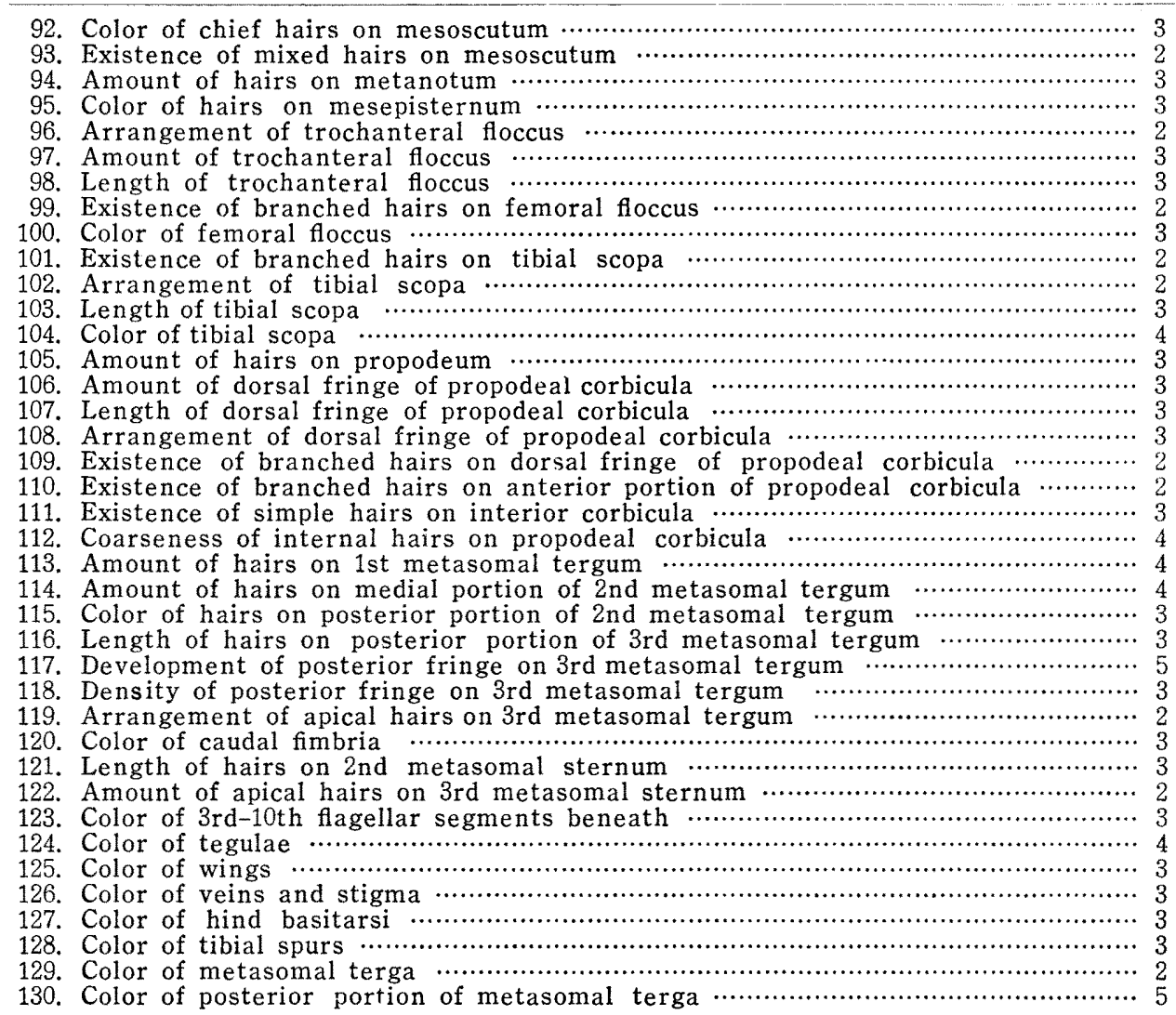

\section{Methods}

The following operations were performed. Pearson's product-moment correlation coefficient and average Euclidian distance coefficient (taxonomic distance of Sokal, 1961) were used to compute each pair of OTU's in order to obtain correlation and distance matrices. Various cluster analyses were used to summarize the phenetic relationships in terms of clusters from these original matrices. In the present study the following five clustering methods were employed:

1. Furthest neighbor method (Lance and Williams, 1967)

2. Group average method (Lance and Williams, 1967)

3. Flexible method (Lance and Williams, 1967)

4. Flexible group-average method (Lance and Williams, 1967)

5. Ward method (Ward, 1963)

The following Lance and Williams' combinational formula (Lance and Williams, 1967) was applied to the above five methods. 


$$
d_{h k}=\alpha_{i} d_{h i}+\alpha_{j} d_{h j}+\beta d_{i j}+\gamma\left|d_{h i}-d_{k j}\right|,
$$

where $d_{i j}$ stands for the distance between a cluster $i$ and a cluster $j, d_{h k}$ is the distance between a cluster $k$ (cluster $i$ +cluster $j$ ) and a cluster $h$ which does not admit a cluster $k$, and $\alpha_{i}, \alpha_{j}, \beta$ and $\gamma$ are parameters.

Furthest neighbor method is known as the complete linkage method by Sneath and Sokal (1973) or the maximum method by Johnson (1967). In this method similarity or dissimilarity is computed as a value between an OTU that is a candidate for an extant cluster and the furthest member within the extant cluster.

Lance and Williams (1967) proposed a flexible clustering method which overcomes the disadvantages of nearest neighbor and furthest neighbor methods. They imposed four constraints upon their linear formula for combinational strategy, as follows:

$$
\alpha,+\alpha_{k}+\beta=1, \quad \alpha_{j}=\alpha_{k}, \quad \beta<1, \quad \gamma=0 .
$$

By adjusting the value of $\beta$ from 1 to -1 , Lance and Williams were able to simulate the results of chaining by nearest neighbor method and of extremely compact clustering by furthest neighbor method. In the present study -0.25 was adopted as the value of $\beta$.

Sokal and Michener (1958) developed average linkage method. This method requires computation of some kind of average similarity or dissimilarity between a candidate OTU or a cluster and an extant cluster. In the average linkage techniques the group average method (UPGMA, unweighted pair-group method using arithmetic averages) has been frequently used. The group average algorithm computes the average similarity or dissimilarity of a candidate OTU to an extant cluster, weighing each OTU in that cluster equally.

Ward (1963) developed the hierarchical grouping method, which is called the Ward method in the present study. This method starts out with $t$ separate OTU's ( $t$ is the number of OTU's) grouping them successively into $t-1$, $t-2, t-3 \cdots \cdots, 1$ OTU and computing a so-called objective function at each stage. This is some measure of the desirability of the particular arrangement of the $t$ OTU's into $k<t$ OTU's at any stage. Such objective function is used as the "loss of information".

\section{RESULTS AND DISCUSSION}

Phenograms obtained by the various clustering methods are discussed below under separate headings. The cophenetic correlation coefficient (Sokal and Rohlf, 1962) was used to judge the degree of the fitness of the resulting phenograms to the original matrices. The taxonomic significances of the groupings at the subgeneric level were considered by drawing some arbitrary phenon line. Plotting ranked similarity diagrams (Moss, 1968), which indicated the original similarity or dissimilarity matrix, were also used to observe the displacement of OTU's in the phenograms. 


\section{A comparison of phenograms based on distance and correlation coefficients}

In this part two phenograms are compared. One is based on a distance (standardized distance) matrix, and the other is based on a correlation one. The group average method of Lance and Williams (1967) was used to summarized the phenetic relationships.

A distance phenogram in Fig. 1 summarized the relationships given by the distance matrix. The code numbers of the OTU's and subgeneric codes are given in Table 1. The cophenetic correlation coefficient for the distance phenogram was relatively high (0.912). A line drawn through the phenogram corresponding to a distance value of 1.25 divided the OTU's into groupings identical with most of the recognized subgenera. The line produced the following 23 groups (Fig. 1): 1) Andrena (2-66 cluster), 2) Larandrena (63-69 cluster), 3) Euandrena (24-70 cluster), 4) Hoplandrena (38-40 cluster), 5) Cnemidandrena (21-23 cluster), 6) Gymnandrena (32-30 cluster), 7) Simandrena (56-85 cluster), 8) Micrandrena (43-42 cluster), 9) Notandrena I (50-51 cluster), 10) Poecilandrena (55 cluster), 11) Notandrena II (52 cluster), 12) Calomelissa (14-15 cluster), 13) Oreomelissa (17-16 cluster), 14) Taeniandrena (59 cluster), 15) Habromelissa (34 cluster), 16) Chlorandrena (19-18 cluster), 17) Stenomelissa (58 cluster), 18) Mitsukuriella (48-49 cluster), 19) Plastandrena (54 cluster), 20) Trachandrena (60-61 cluster), 21) Holandrena I (36-37 cluster), 22) Holandrena II (35 clsuter), and 23) Parandrena (53 cluster). OTU's of the same subgenus were clustered tightly together, for instance, in Euandrena, Hoplandrena, Cnemidandrena, Simandrena, and Micrandrena. However, the line also divided the OTU's in the same subgenus into two groups in Holandrena, i.e., the ishikawai-taniguchiae cluster (36-37) and the valeriana cluster (35), which connected at the distance value of 1.33 with each other. The following was a list of the in. teresting results indicated by the distance phenogram: 1) mikado A-ishiharai cluster (2-4) including five OTU's was extremely separated from the other OTU's of the same subgenus Andrena, showing the connecting distance value of $1.23,2$ ) although the OTU's of the Gymnandrena were clustered together with one another, they connected at relatively higher distance values, especially in the juncture of parathoracica (30) with the other OTU's at a distance value of $1.23,3$ ) amamiensis (52) was relatively separated from the other OTU's of the Notandrena and it did not connect with the nitidiuscula-richardsi cluster (50-51) but with the nitidiuscula-fukwokensis cluster (50-55) at the value of $1.29,4)$ the Calomelissa cluster $(14-15)$ was relatively close to the Oreomellissa cluster (17-16), showing the connecting value of $1.25,5)$ taraxaci chikuzenensis (18) was relatively close to the knuthi-knuthi okinawana cluster (19-20), showing the value of 1.08. Above the subgeneric level five major groups were developed as follows: 1) Andrena, Larandrena, Euandrena, Hoplandrena, Cnemidandrena, Gymnandrena, Simandrena, 2) Micrandrena, Notandrena I, Poecilandrena, Notandrena II, Calomelissa, Oreomelissa, Taeniandrena, Habromelissa, 3) Chlorandrena, Stenomelissa, 4) Mitsukuriella, Plastandrena, Trachandrena, Holandrena I, Holandrena II, 5) Parandrena.

The other phenogram (Fig. 2) produced by the group average method was 


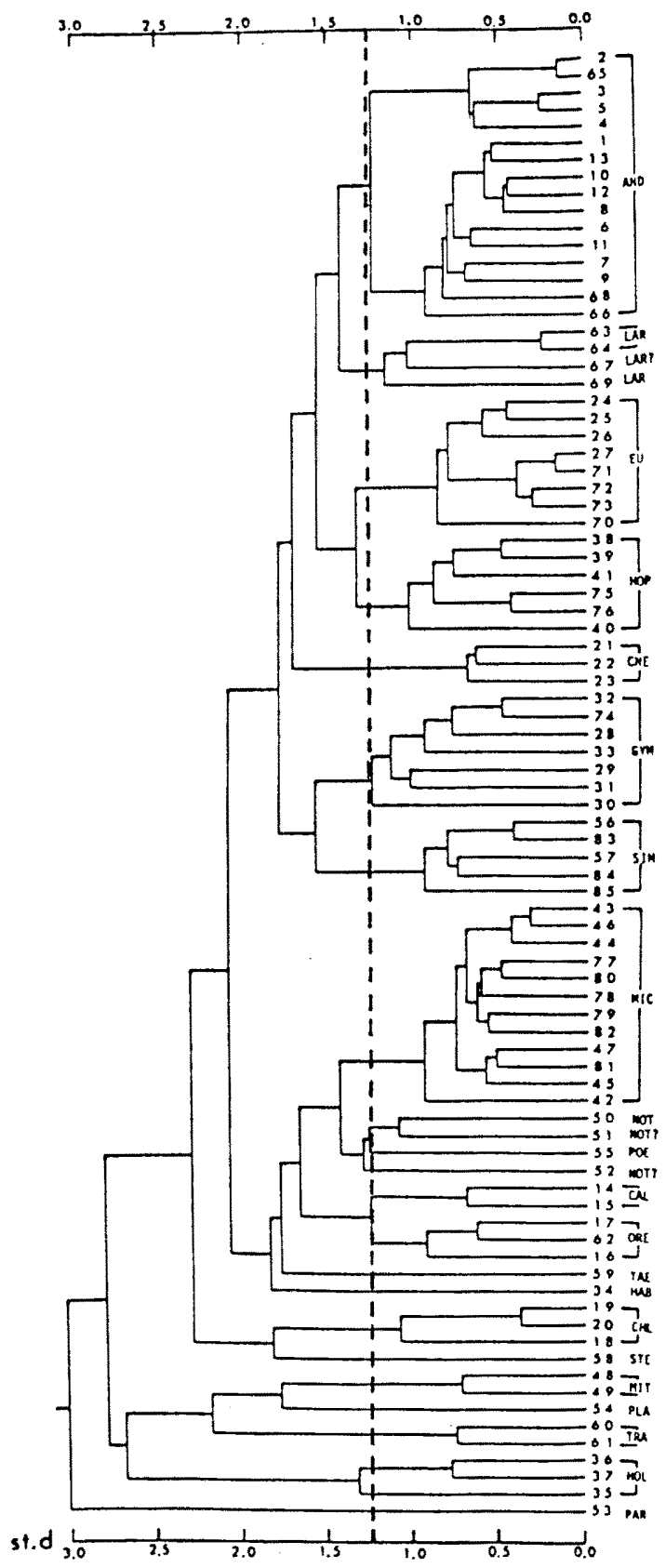

Fig. 1. Distance phenogram obtained by the group average method based on 130 characters derived from 85 OTU's. 


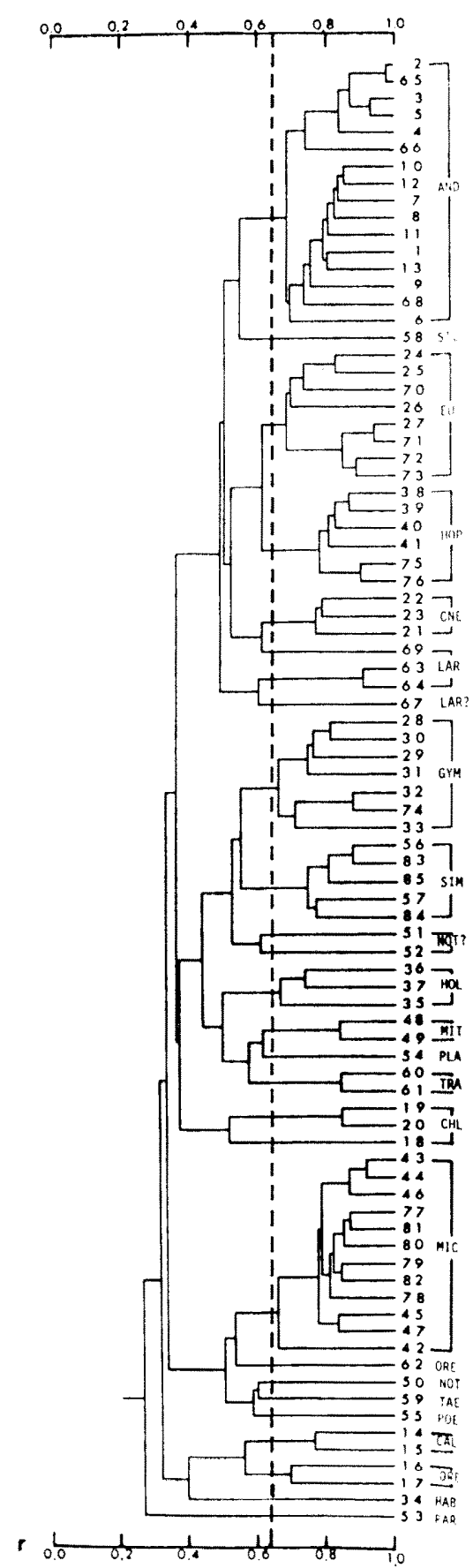

Fig. 2. Correlation phenogram obtained by the group average method based on 130 characters derived from 85 OTU's. 


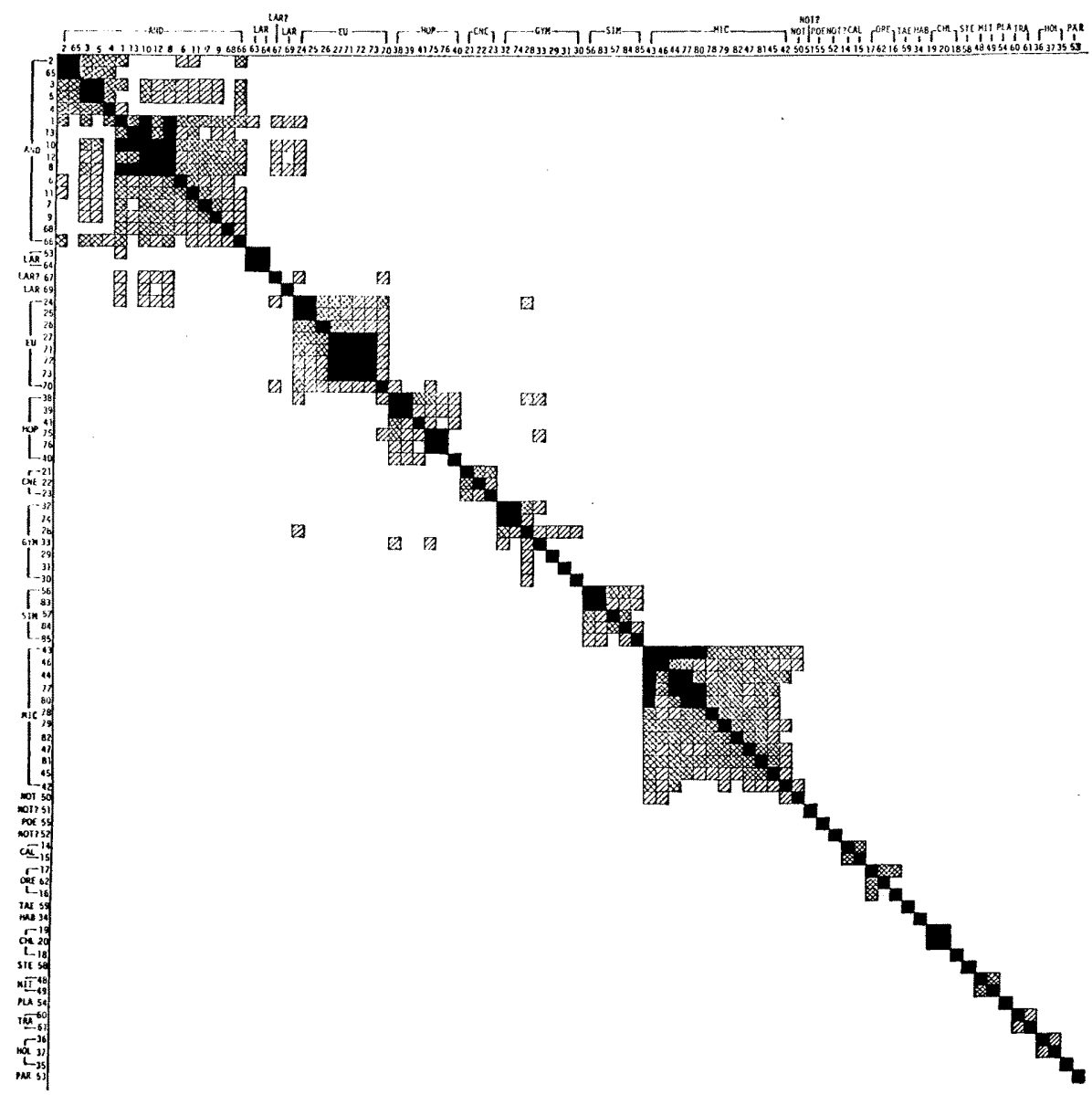

Fig. 3. Plotting ranked similarity diagram based on the distance matrix.

based on the correlation matrix. The cophenetic correlation coefficient was 0.846. The results obtained from this procedure were basically similar to the preceding distance phenogram. The phenon line at the correlation value of 0.62 separated the OTU's into groupings identical with most of the recognized subgenera. The principal differences evident in this phenogram were as follows: 1) A. (Andrena) sp. 4 (69) was extremely isolated from the other OTU's of Andrena (2-6 cluster) and connected with Cnemidandrena cluster $(22-21), 2)$ the richardsi-amamiensis cluster (51-52) was extremely separated from nitidiuscula $(50), 3)$ coitana pilosodorsata (62) was isolated from the other OTU's (16-17) of Oreomelissa and clustered with Micrandrena cluster (43-42), 4) the ishikawai-taniguchiae cluster (36-37) was relatively close to valeriana (35), showing the correlation value of $0.67,5)$ taraxaci chikuzenensis (18) was comparatively separated from the knuthi-knuthi okinawana cluster (19-20), showing the value of 0.52 . 


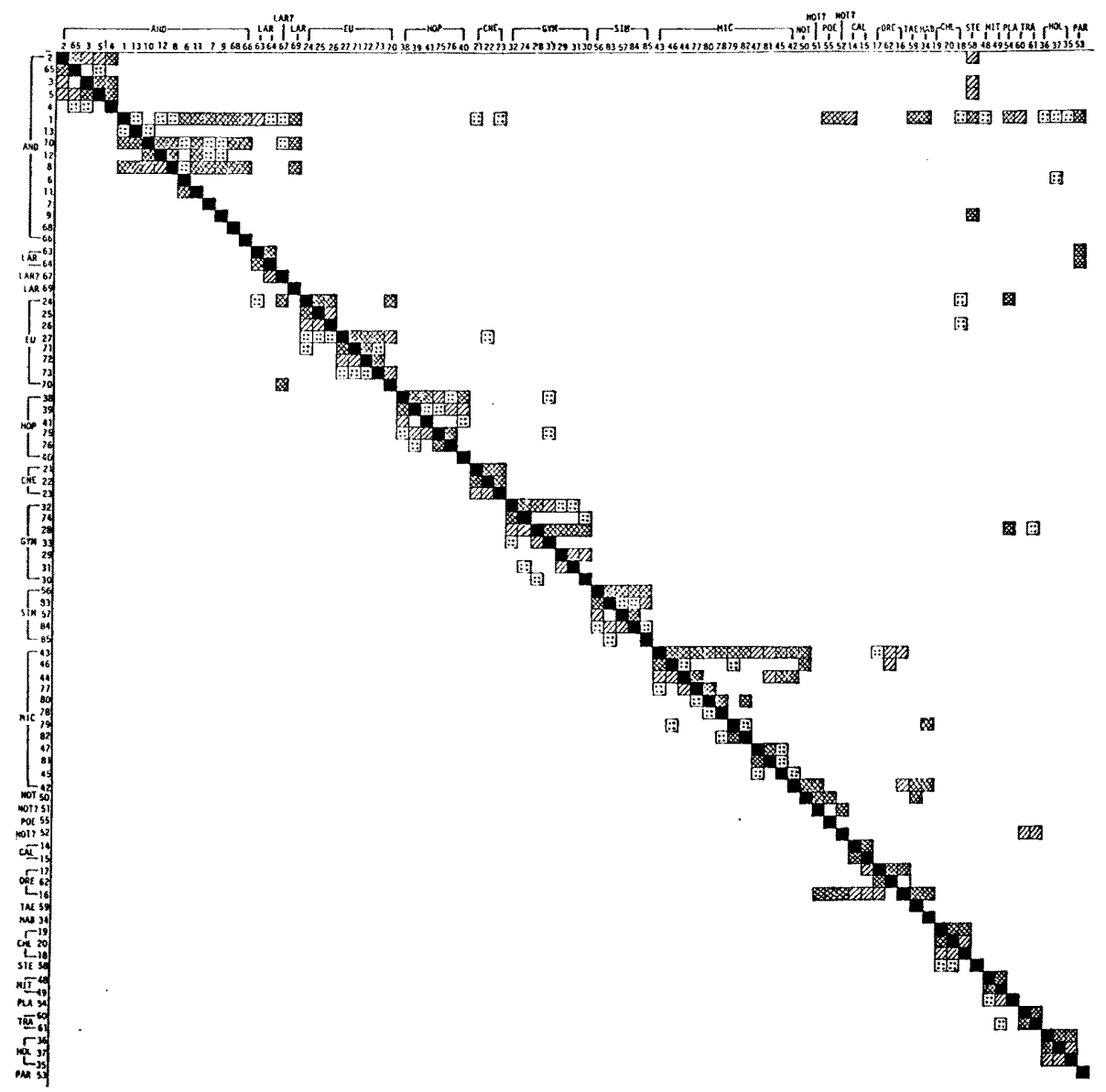

Fig. 4. Plotting ranked similarity diagram based on the correlation matrix.

One method of comparing clustering techniques is to compute their correlations with each other, using the cophenetic values obtained from their respective phenograms. Thus the distance phenogram derived from the distance matrix showed higher cophenetic correlation value as mentioned above. Although this operation indicates that clustering methods are closest to each other in the placement of OTU's, it does not provide information on the content of the actual clusters themselves. Figs. 3-4 show plotting ranked similarity diagrams. In these figures the vertical and horizontal sequence of OTU's is determined by the order in the distance phenogram. Similarity or dissimilarity values derived from the original matrices are plotted columnwise for each OTU. It can be seen from the distance diagram (Fig. 3) that the black squares indicating first-order similarity (distance value;0.00-0.50) are all placed along the diagonal or at most a few squares away from it. Thus it shows that adjacent OTU's in the distance phenogram are most closely re- 
lated to each other. Where among the adjacent OTU's mutually highest similarities are involved, a square is formed, e.g., for three OTU's (21-23) of Cnemidandrena. In case of second-order (cross oblique squares, distance value; $0.51-0.85$ ) and third-order (oblique squares, distance value; $0.86-1.00$ ) distances, the majority of these are also situated along the diagonal, with some exceptions of the third-order relationship. It can be said that the phenogram can be checked by the displacements of the OTU's in this diagram. From the arrangement of squares in the distance diagram, it is obvious that the distance phenogram shows comparatively exact content of the original ma. trix. However, the diagram indicates that $A$. (Andrena) sp. 2 (67) and $A$. (Andrena) sp. 4 (69) are more closely related to the subgenus Andrena than can be shown in the phenogram. The subgenus Andrena, which was divided into two groups in the phenogram, clustered loosely together as a whole. The diagram agrees with the phenogram on the separation of valeriana from the ishikawai-taniguchiae cluster. It also shows that three OTU's of Notandrena are isolated from one another. It indicates that Gymnandrena is one loosely connected group. The OTU taraxaci chikuzenensis is further separated from the knuthi-knuthi okinawana cluster than can be shown in the phenogram. The similar relationship is found between the Oreomelissa and the Calomelissa. The subgenera Cnemidandrena, Simandrena, Poecilandrena, Calomelissa, Oreomelissa, Mitsukuriella, Trachandrena, Habromelissa, Stenomelissa, Plastandrena, and Parandrena are considered to be distinct groups because they do not connect with any OTU's of the other subgenera in the plotting ranked similarities.

Fig. 4 shows the plotting ranked similarity diagram based on the correlation matrix. Although the vertical and horizontal sequence of OTU's are determined by the order in the distance phenogram, it is obvious that the distance diagram is much more congruent with the conventional classification than the correlation one. The correlation diagram shows that the correlation phenogram has many displacements of OTU's. For instance, A. (Andrena) sp. 4 (69) connected with the Cnemidandrena cluster in the phenogram, however it is more closely related to a few OTU's (1, 10, and 8 ) of the subgenus Andrena in the diagram.

Sokal and Michener (1967) found that correlation phenograms were much more congruent than distance ones with the conventional classification. However, the above result shows that the distance phenogram is much more congruent with the original matrix and the conventional classification.

\section{A comparison of phenograms based on five clustering methods}

In this part five clustering methods are compared based on the distance matrix of the 130 original characters derived from 85 OTU's. Fig. 1 and Figs. 5-8 show the five distance phenograms produced by the five different cluster. ing methods. The results obtained from the group average method were formally used as standard in order to compare with those from the other methods. 
(1) Group average method (Fig. 1)

This method showed the highest value of cophenetic correlation coeffi-

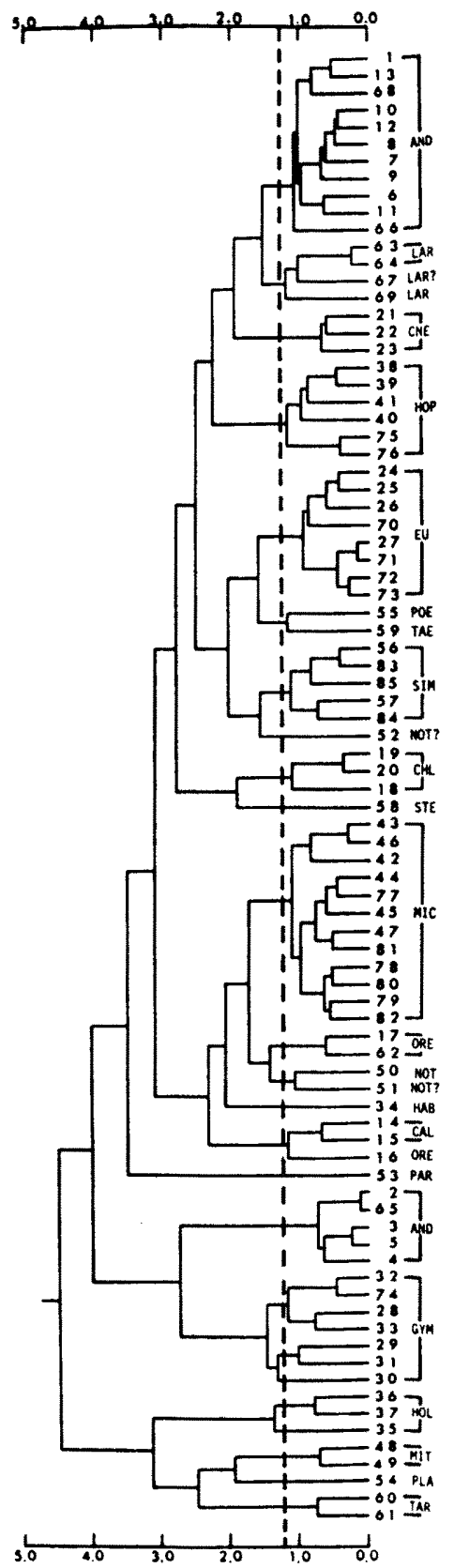

Fig. 5. Distance phenogram obtained by the furthest neighbor method based on 130 characters derived from 85 OTU's. 


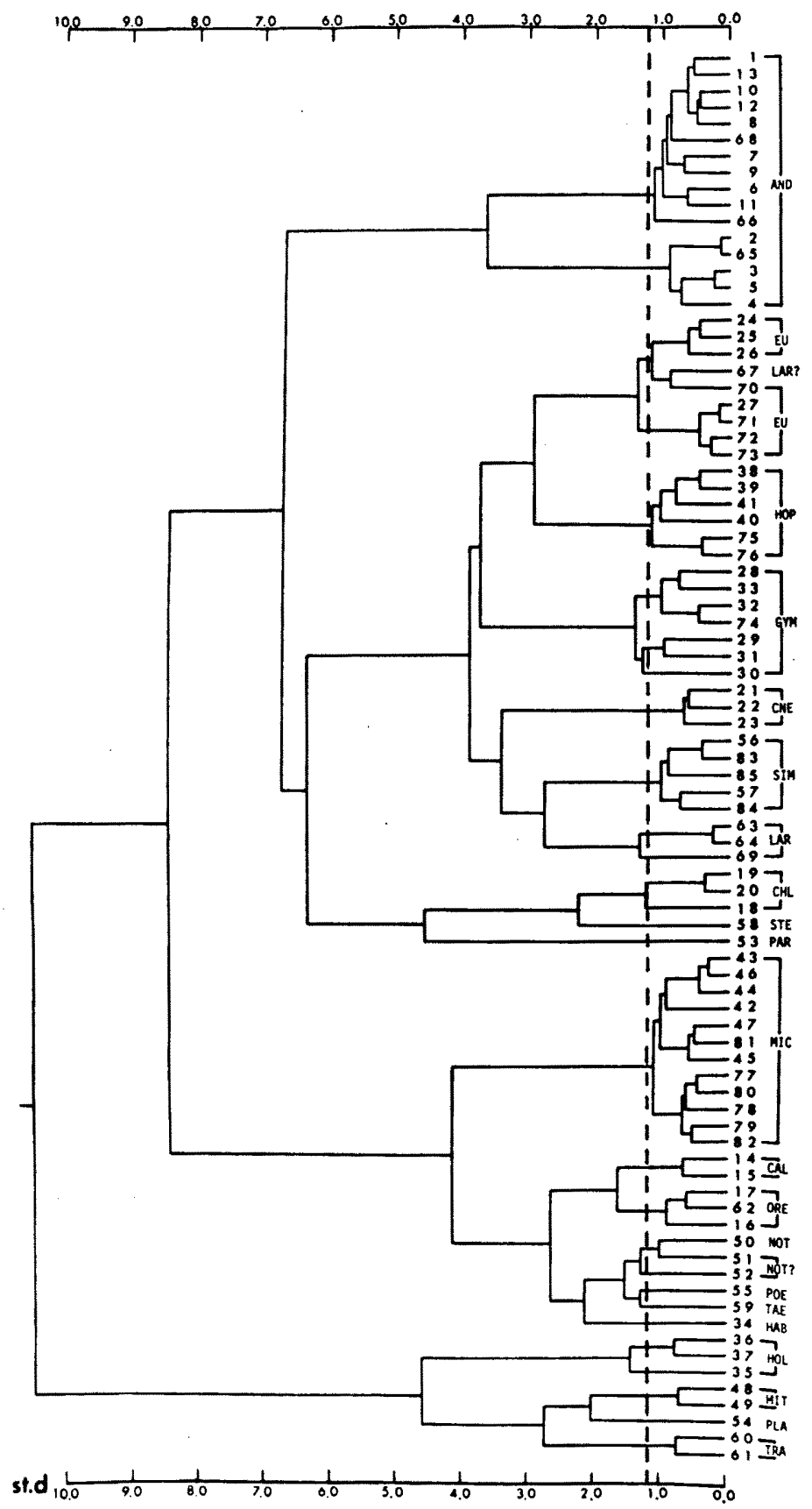

Fig. 6. Distance phenogram obtained by the flexible group-average method based on the 130 characters derived from 85 OTU's. 


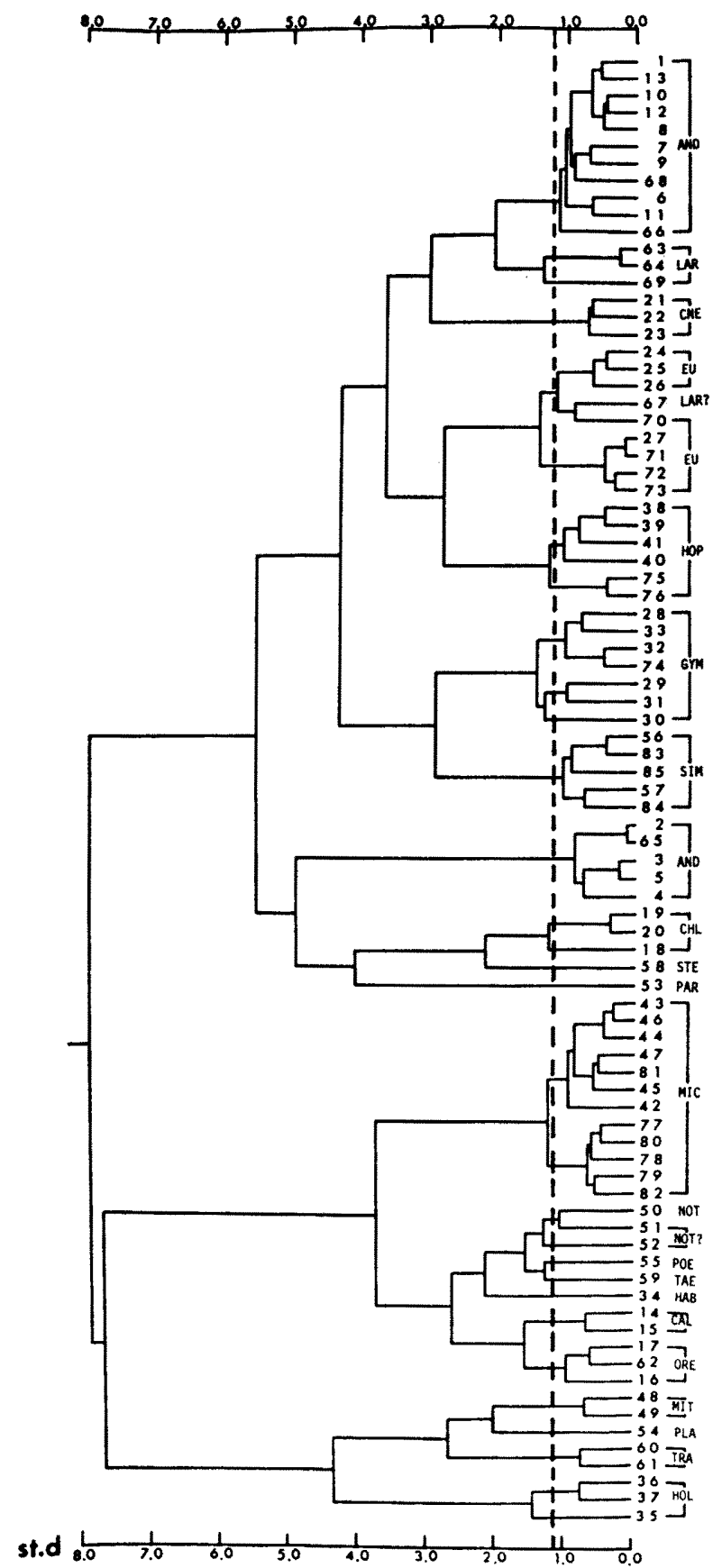

Fig. 7. Distance phenogram obtained by the flexible method based on 130 characters derived from 85 OTU's. 
cient as mentioned above.

(2) Furthest neighbor method (Fig. 5)

The results obtained from this method were basically similar to the above method. The brevihirtiscopa-A.(Andrena) sp. 1 cluster (1-66) of the subgenus Andrena connected with the Larandrena cluster (63-69) and extremely separated from the mikado A-ishiharai cluster (1-4). The other differences evident in this phenogram were as follows: 1) mitakensis (16) clustered with Calomelissa cluster (14-15) and separated from Oreomelissa cluster, 2) amamiensis (52) strongly isolated from nitidiuscula (50) and richardsi (51).

\section{(3) Flexible group-average method (Fig. 6)}

The results derived from this procedure were similar to the above phenograms. However, the higher distance level is prolonged in this method Two groups of the subgenus Andrena clustered with each other at the higher distance value of 3.67. The OTU $A$. (Andrena) sp. 2 (67) strongly isolated from the Larandrena cluster $(63,67)$ and joined the Euandrena cluster (24-73). This phenogram indicated that the subgenus Gymnandrena is composed of OTU's widely separated from one another. Oreomelissa (17-16) was well separated from Calomelissa (14-15), showing the connecting value of 1.65 . The three OTU's of Notandrena clustered with one another at the relatively lower distance value of 1.33. The ishikawai-taniguchiae cluster (36-37) considerably separated from valeriana (35), showing the connecting value of 1.46.

\section{(4) Flexible method (Fig. 7)}

The results of this method considerably resembled to the preceding one. The important difference observed in this phenogram was the strong isolation of mikado A-ishiharai cluster (2-4) from the other OTU's of the subgenus Andrena. The OTU A. (Andrena) sp. 2 (67) also joined the Euandrena cluster (24-73).

\section{(5) The Ward method (Fig. 8)}

In case of this method the stem at the higher distance level was quite elongated. This is a distinctive feature of this method. At the lower distance level this method also produced basically similar groupings as the previous ones. One group (10-11) of the subgenus Andrena connected with the OTU's (63-69) of the Larandrena and then clustered with the mikado group (3-65). In this phenogram A. (Andrena) sp. 2 (69) joined the OTU's of Euandrena (24-75). This relationship was also observed in the flexible and the flexible groupaverage methods.

From an inspection of the five phenograms it seems that they share a number of similarities in their groupings. The taxonomic significances of the groupings within the major groups are considered by drawing some arbitrary phenon line. Such a line cuts the stem and results in defining a number of groups. Tadauchi (1978) already compared six clustering methods by similar fashion at the major clustering level, which was above the subgeneric level. In the present study the comparing level is lowered to the subgeneric level. 
Because it has been found that cluster analysis has more distortions at the higher distance level than at the lower distance level. Emphasis also has been given on the examination of the position of each OTU in the genus Andrena of Japan. Therefore the distance scale of 1.25, which was adopted

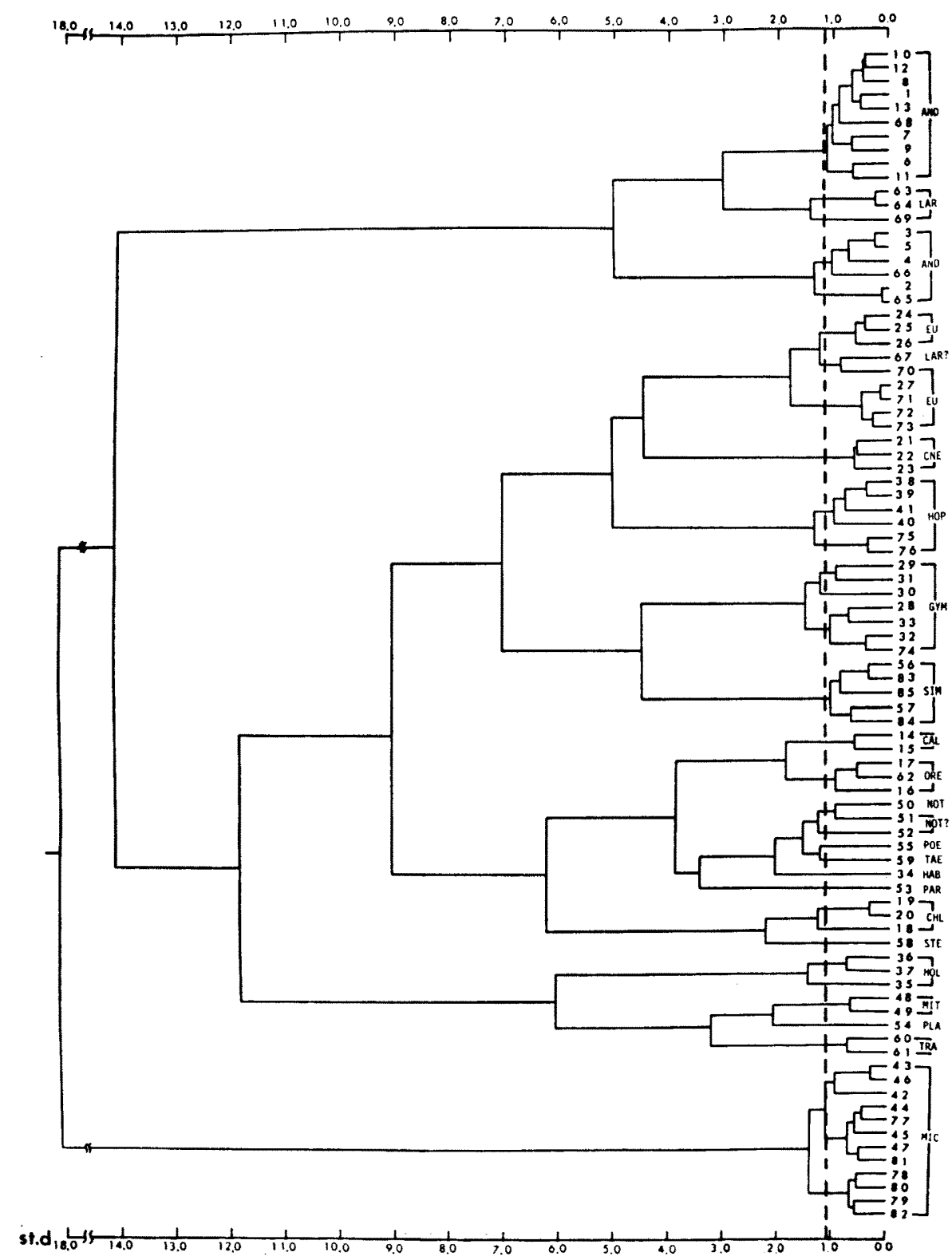

Fig. 8. Distance phenogram obtained by the Ward method based on 130 characters derived from 85 OTU's. 
Table 3. Groupings obtained by five clustering methods based on the values of distance coefficient. Criterion of group recognition is a line drawn across the phenogram at the 1.25 level of the distance scale. The presence or absence of a group is denoted by a " + " or a " - ".

\begin{tabular}{|c|c|c|c|c|c|c|}
\hline \multicolumn{2}{|c|}{ Subg. code } & \multirow{2}{*}{$\frac{\text { Group Av. }}{+}$} & \multirow{2}{*}{$\underbrace{\text { Furth. N. }}_{-}$} & \multirow{2}{*}{$\begin{array}{c}\text { Flexible } \\
\text { Group-Av. } \\
-\end{array}$} & \multirow{2}{*}{$\begin{array}{c}\text { Flexible } \\
-\end{array}$} & \multirow{2}{*}{$\frac{\text { Ward }}{-}$} \\
\hline AND & $(1-3,66,68)$ & & & & & \\
\hline AND & $(1,6-13,66,68)$ & - & + & + & + & - \\
\hline AND & $(2,3,4,5,65)$ & - & + & + & + & - \\
\hline LAR & $(63,64,67,69)$ & + & + & - & - & - \\
\hline LAR & $(63,64)$ & - & - & + & + & + \\
\hline LAR & (69) & - & - & + & + & + \\
\hline EU & $(24-27,70-73)$ & + & + & - & - & - \\
\hline EU & $(24,25,26,67,70)$ & - & - & + & + & - \\
\hline $\mathrm{EU}$ & $(27,70,72,73)$ & - & - & + & + & + \\
\hline $\mathrm{EU}$ & $(67,70)$ & - & - & - & - & + \\
\hline EU & $(24,25,26)$ & - & - & - & - & + \\
\hline HOP & $(38-41,75-76)$ & + & + & + & - & - \\
\hline HOP & $(38-41)$ & - & - & - & + & + \\
\hline $\mathrm{HOP}$ & $(75,76)$ & - & - & - & + & + \\
\hline $\mathrm{CNE}$ & $(21-23)$ & + & + & + & + & + \\
\hline GYM & $(28-33,74)$ & + & - & - & - & - \\
\hline GYM & $(28,32,33,74)$ & - & + & + & + & + \\
\hline GYM & $(29,31)$ & - & + & + & + & + \\
\hline GYM & $(30)$ & - & + & + & + & + \\
\hline SIM & $(56-57,83-85)$ & + & + & + & + & + \\
\hline MIC & $(42-47,77-82)$ & + & + & + & + & - \\
\hline MIC & $(42-47,77,81)$ & - & - & - & - & + \\
\hline MIC & $(78,79,80,82)$ & - & - & - & - & + \\
\hline NOT & $(50,51)$ & + & + & + & + & + \\
\hline ? NOT & $(52)$ & + & + & + & + & + \\
\hline POE & $(55)$ & + & + & + & + & + \\
\hline $\mathrm{CAL}$ & $(14-15)$ & + & - & + & + & + \\
\hline CAL & $(14,15,16)$ & - & + & - & - & - \\
\hline ORE & $(16-17,62)$ & + & - & + & + & + \\
\hline ORE & $(17,62)$ & - & $t$ & - & - & - \\
\hline TAE & $(59)$ & + & + & + & + & + \\
\hline $\mathrm{HAB}$ & (34) & + & + & + & + & + \\
\hline CHL & $(18-20)$ & + & + & - & - & - \\
\hline $\mathrm{CHL}$ & $(19-20)$ & - & - & + & + & + \\
\hline $\mathrm{CHL}$ & (18) & - & - & + & + & + \\
\hline STE & (58) & $t$ & + & + & + & + \\
\hline MIT & $(48-49)$ & + & + & + & + & + \\
\hline PLA & $(54)$ & + & + & + & + & + \\
\hline TRA & $(60-61)$ & + & + & + & + & + \\
\hline PAR & (53) & + & + & + & + & + \\
\hline $\mathrm{HOL}$ & $(35)$ & + & + & + & + & + \\
\hline $\mathrm{HOL}$ & $(36-37)$ & + & + & + & + & + \\
\hline
\end{tabular}

in the first comparison is preferred. Table 3 shows the groupings produced by this line concerning the five phenograms. In the table the presence of the groups obtained at the recognition line of 1.25 is denoted by a " + ", and its absence by a "-". As shown in Table 3 it is recognized that the results obtained by the furthest neighbor method are similar to those by the group average method. The flexible method has a great resemblance to that by the flexible group-average method except for the grouping of the subgenus Hoplandrena. The Ward method is basically similar to the two flexible methods. Throughout the clustering methods many subgenera or OTU's are fairly consistent in their formation of groupings at the recognition level 
chosen. They are the following 14 groups: Cnemidandrena (21-23), Simandrena (56-57, 83-85), Poecilandrena (55), nitidiuscula + richardsi (50, 51), amamiensis (52), Taeniandrena (59), Habromelissa (34), Stenomelissa (58), Mitsukuriella (48-49), Plastandrena (54), Trachandrena (60-61), Parandrena (53), valeriana (35), and ishikawai+ taniguchiae $(36,37)$. However, clustering within these groupings is somewhat variable. As expected on theoretical grounds, the four methods except for the group average method produce groupings that were slightly more diverse or elongated than those formed by the group average one. For instance, OTU's of the subgenus Gymnandrena clustered with one another before the phenon line in the group average method. On the other hand, it was divided into three separate groups in the other four methods. The number of the groups produced by the line are 23 groups for the group average, 26 for the furthest neighbor, 29 for the flexible group-average, 30 for the flexible and 33 for the Ward method. Taking the plotting ranked diagram (Fig. 3 ) and the original matrix into consideration, some displacements of the OTU's in the phenograms are found at the subgeneric level. For example, mitakensis (16) was transferred from the Oreomelissa cluster in the furthest neighbor method. It is obvious that the subgenus Andrena is composed of two distinct groups. In the furthest neighbor and flexible methods the two groups of the subgenus Andrena were strongly isolated from each other and clustered with the other subgenus, respectively. These are considered to be the examples of the distortions judged from the original matrix. Among the five phenograms the group average method has the fewest distortions in the groupings at the phenon line level. Lance and Williams (1967) pointed out that contraction or dilation in space influences results of cluster analysis. The nearest neighbor method contracts the space, while the furthest neighbor method dilates it. The flexible method controls the space by the value of parameter $\beta$ in Lance and Williams' combinational formula. In the present study -0.25 was applied as the value of the parameter. The results by the Ward method are nearly similar to the flexible methods at 1.25 level of the distance scale. At least concerning the cophenetic correlation coefficient, the Ward method shows a relatively low value because of a quite elongate results at the higher distance level

\section{GROUPING OF OTU'S OF THE GENUS ANDRENA OF JAPAN}

The following 23 groups are developed taking the above discussion into consideration.

1. 1st group (subgenus Andrena)

(1) mikado group

mikado A (2), mikado B (65), nawai (5), bombiformis (3), ishiharai (4)

(2) benefica group

benefica (13), brevihirtiscopa (1), hondoica (10), saragamineensis (12), maukensis (8), esakii (6), aburana (11), longitibialis (7), shirozui (9), (Andrena) sp. 3 (68), (Andrena) sp. 1 (66)

(3) (Andrena) sp. 2 group 
(Andrena) sp. 2 (67), (Andrena) sp. 4 (69)

2. 2nd group (subgenus Larandrena) echizenia (63), fukuiana (64)

3. 3rd group (subgenus Euandrena) hebes (24), stellaria (25), ruficrus rabicrus (26), takachihoi A (27), takachihoi B (71), takachihoi C (72), takachihoi D (73), (Euandrena) sp. 1 (70)

4. 4th group (subgenus Hoplandrena) dentata (38), miyamotoi (39), pruniphora (41), (Hoplandrena) sp. 1 ssp. 1 (75), (Hoplandrena) sp. 1 ssp. 2 (76), sachalinensis (40)

5. 5th group (subgenus Cnemidandrena) seneciorum (21), maetai (22), albicaudata (23)

6. 6th group (subgenus Gymnandrena) edashigei A (32), edashigei B (74), watasei (28), sasakii (33), wulungshanensis (29), okabei sapporensis (31), parathoracica (30)

7. 7th group (subgenus Simandrena) opacifovea (56), (Simandrena) sp. 1 (83), kerriae (57), (Simandrena) sp. 2 (84), (Simandrena) sp. 3 (85)

8. 8th group (subgenus Micrandrena) brassicae (43), sublevigata (46), kaguya A (44), (Micrandrena) sp. 1 (77), (Micrandrena) sp. 4 (80), (Micrandrena) sp. 2 (78), (Micrandrena) sp. 3 (79), kaguya B (82), falsificissima (47), komachi B (81), komachi A (45), hikosana (42)

9. 9th group (subgenus Notandrena)

(1) nitidiuscula group nitidiuscula (50)

(2) richardsi group richardsi (51)

10. 10th group (Subgenus? Notandrena sensu Hirashima, 1965) amamiensis (52)

11. 11th group (subgenus Poecilandrena) fukuokensis (55)

12. 12th group (subgenus Calomelissa) prostomias (14), tsukubana (15)

13. 13th group (subgenus Oreomelissa) kamikochiana (17), coitana pilosodorsata (62), mitakensis (16)

14. 14th group (subgenus Taeniandrena) ezoensis (59)

15. 15th group (subgenus Habromelissa) omogensis (34)

16. 16th group (subgenus Chlorandrena)

(1) knuthi group (subgenus Chlorandrena sensu Hirashima, 1963) knuthi (19), knuthi okinawana (20)

(2) taraxaci group taraxaci chikuzenensis (18)

17. 17th group (subgenus Stenomelissa) 


\section{halictoides (58)}

18. 18th group (subgenus Mitsukuriella)

japonica (48), fukaii (49)

19. 19th group (subgenus Plastandrena)

astragalina (54)

20. 20th group (subgenus Trachandrena)

foveopunctata (60), haemorrhoa japonibia (61)

21. 21st group (subgenus Holandrena)

valeriana (35)

22. 22nd group (subgenus Holandrena sensu Hirashima, 1964) ishikawai (36), taniguchiae (37)

23. 23rd group (subgenus Parandrena)

yasumatsui (53)

As mentioned above, there are three main differences in comparison with the conventional classification as follows:

1) The ishikawai-taniguchiae group, which was classified into the subgenus Holandrena by Hirashima (1964), is recognized better to be raised to the subgeneric level.

2) The OTU amamiensis, whose position at the subgeneric level was left in doubt by Hirashima (1965), is recognized better to be separated from the subgenus Notandrena.

3) The knuthi-knuthi okinawana group placed in the subgenus Chrysandrena by Hirashima (1963) is transferred to the subgenus Chlorandrena.

\section{ACKNOWLEDGEMENTS}

I am greately indebted to Prof. Y. Hirashima of Kyushu University for making this study possible and his valuable advices on andrenid bees. My sincere thanks are due to Prof. $\mathrm{Ch}$. Asano of Research Institute of Fundamental Information Science of Kyushu University for his valuable advices on multivariate statistics. I also wish to express my hearty thanks to Prof. Emerit. T. Okada of Tokyo Metropolitan University for his kind guidance to numerical taxonomy and encouragement. I am also grateful to Assoc. Prof. K. Morimoto and Mr. K. A. Sahad of Kyushu Univesity, Prof. S. Sakai of Daito Bunka University for their helpful advices and suggestions.

My cordial thanks are due to the following entomologists, who kindly loaned me their large and valuable collections of Andrena species: Assoc. Prof. Y. Maeta of Shimane University, Prof. S. F. Sakagami and Assoc. Prof. H. Fukuda of Hokkaido University, Assoc. Prof. M. Munakata of Hakodate College, Hokkaido University of Education, and Mr. Y. Haneda of Ono City, Fukui Pref.

Thanks are also due to Mr. T. Mizukubo of Nagasaki Pref. for his help in many ways. 


\section{REFERENCES}

Cockerell, T. D. A. 1911 Bees in the collection of the United States National Museum. 2. Proc. U.S. nat. Mus., $40: 241-264$

Hedicke, H. 1933 Beiträge zur Systematik der Gattung Andrena F. (Hym. Apoid.). Mitt. Zool. Mus. Berlin, 19: 199-220

Hirashima, Y. 1962-1966 Systematic and biological studies of the family Andrenidae of Japan (Hymenoptera, Apoidea). Part I. Biology, Part II. Systematics 1-7. J. Fac. Agr., Kyushu Univ., 12: 1-20, 117-154, 241-263; 13: 39-69, 71-97, 461-491, 493-517; 14: 89-131

Hirashima, Y. and Y. Haneda 1973 New or little known species of the genus Andrena from Japan (Hymenoptera, Andrenidae). Mushi, 47: 67-73

Hirashima, Y. and O. Tadauchi 1975 A new subgenus of the genus Andrena (Hymenoptera, Andrenidae) from Japan and allied areas. J. Fac. Agr., Kyushu Univ., 19: 175-186

Johnson, S. C. 1967 Hierarchical clustering schemes. Psychometrika, 32: 241-254

LaBerge, W. E. 1964 Prodromus of American bees of the genus Andrena (Hymenoptera, Apoidea). Bull. Univ. Nebraska State Mus., 4: 275-316

Lanham, U. N. 1949 A subgeneric classification of the new world bee the genus Andrena. Univ. Calif. Pub. Ent., 8: 183-237

Lance, G. N. and W. T. Williams 1967 A general theory of classificatory sorting strategies. I. Hierarchical systems. Computer J., 9: 373-380

Molina-Pardo, A. 1973 A phenetic analysis of new world bees of five subgenera of the genus Andrena (Hymenoptera: Apoidea). Doctor thesis for the $\mathrm{Ph}$. D. in Univ. Illinois. $181 \mathrm{pp}$.

Moss, W. W. 1968 Experiments with various techniques of numerical taxonomy. Syst. Zool., 17: $31-47$

Sneath, P. H. A. and R. R. Sokal 1973 Numerical Taxonomy. W. H. Freeman and Company, San Francisco

Sokal, R. R. 1961 Distance as a measure of taxonomic similarity. Syst. Zool., 10:70-79

Sokal, R. R. and C. D. Michener 1967 The effects of different numerical techniques on the phenetic classification of bees of the Hoplitis complex (Megachilidae). Proc. Linn. Soc. Lond., 178 : 59-74

Sokal, R. R. and F. J. Rohlf 1962 The comparison of dendrograms by objective methods. Taxon, $11: 33-40$

Tadauchi, O. 1975 Numerical phenetic relationships of the genus Andrena (Hymenoptera, Andrenidae) of Japan, with a new introduction of component pattern diagrams. Kon-

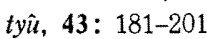

Tadauchi, O. 1978 A comparison of various clustering methods applied to the Japanese andrenid bees. Zool. Magazine, 87: 117-124

Ward, J. H., Jr. 1963 Hierarchical grouping to optimize an objective function. J. Amer, Statist. Ass., 58 : 236-244

Warncke, K. 1968 Die Untergattungen der westpaläarktischen Bienengattung Andrena F. Mem. Est. Mus. Zool. Univ. de Coimbra, (307) : 1-110 